\title{
Larangan Ultra Vires (Exces De Pouvoir) dalam Tindakan Pemerintahan (Studi Komparasi Konsep Antara Sistem Hukum Anglo Saxon Dan Sistem Hukum Kontinental)
}

\author{
Sri Nur Hari Susanto \\ Faculty of Law, Universitas Diponegoro \\ Prof. Soedarto, SH, Street, Tembalang, Semarang \\ Email: srinurharisusanto@lecturer.undip.ac.id
}

\begin{abstract}
This research aims to determine the use of authority by government agencies is legality. Specifically, to find out more about the prohibition of Ultra Vires (Exces De Pouvoir) in Government Actions (Comparative Study of Concepts between the Anglo Saxon Law System and the Continental Legal System). The results of the study indicate that First, the form of government agency action prohibition in the form of excès de pouvoir (ultra vires), both in the Anglo Saxon legal system (Britain, USA, Australia, etc.) and Continental especially France includes also the prohibition of abuse of authority (abuse of power, detournement de pouvoir). Second, the Prohibition of abuse of authority (detournement de pouvoir) in France has been developed into 3 (three) variants, namely the Administrative Agency has the purpose / aims to achieve goals that are entirely other than the public interest, and as a personal goal.
\end{abstract}

Keywords: Prohibition of Ultra Vires, Government Actions, Legal System.

\begin{abstract}
Abstrak
Penelitian inimbertujuan untuk mengetahui Larangan Ultra Vires (Exces De Pouvoir) dalam Tindakan Pemerintahan (Studi Komparasi Konsep Antara Sistem Hukum Anglo Saxon Dan Sistem Hukum Kontinental). Hasil penelitian menjukan bahwa Pertama, Bentuk larangan tindakan badan pemerintah yang berupa excès de pouvoir (ultra vires), baik dalam sistem hukum Anglo Saxon (Inggris, USA, Australia, dll) maupun Kontinental khususnya Prancis meliputi juga larangan penyalahgunaan wewenang (abuse of power, detournement de pouvoir). Kedua, Larangan penyalahgunaan wewenang (detournement de pouvoir) di Prancis telah dikembangkan ke dalam 3 (tiga) varian, yaitu Badan Administrasi memiliki tujuan/bertujuan untuk mencapai tujuan yang sepenuhnya selain bagi kepentingan umum, dan sebagai tujuan pribadi.
\end{abstract}

Kata Kunci: Larangan Ultra Vires, Tindakan Pemerintahan, Sistem Hukum. 


\section{A. Pendahuluan}

Dalam kepustakaan hukum administrasi Belanda, soal wewenang selalu menjadi bagian penting dan bagian awal dari hukum administrasi , karena obyek administrasi adalah wewenang pemerintahan (bestuursbevoegdheid). ${ }^{1}$ Dalam konsep hukum publik, wewenang merupakan suatu konsep inti dari Hukum Tata Negara dan Hukum Administrasi (het begrip bevoegdheid is dan ook een begripen in het staats en administratief recht $)^{2}$.

Setiap badan administrasi dalam menjalankan wewenangnya, idealnya harus menghormati batas-batas yang memisahkan bidang wewenang/kompetensinya dari badan administrasi lainnya. Batas-batas ini ditetapkan berdasarkan yurisdiksi teritorial (ratione loci), sesuai dengan objek (ratione materiae) dan menurut waktu yang tepat (ratione temporis). Di luar batas- batas tersebut maka suatu tindak pemerintahan merupakan suatu tindakan yang tanpa wewenang (onbevoegdheid). Setiap wewenang dengan demikian dibatasi oleh materi (substansi), ruang (wilayah : locus) dan waktu (tempus). Hal ini menjadi ruang lingkup dari legalitas tindak pemerintahan. Tindakan tanpa wewenang dengan demikian dapat berupa onbevoegdheid ratio materiae, onbevoegdheid ratio loci, dan onbevoegdheid ratio temporis. Wewenang dan prosedur merupakan landasan bagi legalitas formal. Atas dasar legalitas formal, lahirlah asas praesumptio iustae causa. ${ }^{3}$

Dalam Hukum Tata Negara, wewenang (bevoegdheid) didesripsikan sebagai kekuasaan hukum (rechtsmacht). Dengan demikian dalam hukum publik, wewenang berkaitan dengan kekuasaan. ${ }^{4}$ Sebagai suatu konsep hukum publik, wewenang terdiri atas sekurangkurangnya tiga komponen, yaitu : pengaruh, dasar hukum, dan konformitas hukum. ${ }^{5}$ Komponen pengaruh artinya penggunaan wewenang dimaksudkan untuk mengendalikan perilaku subjek hukum. Komponen dasar hukum berarti bahwa wewenang itu selalu

${ }^{1}$ Philipus M Hadjon, Tentang Wewenang, Jurnal Yuridika, Volume 7 No 5-6, September - Desember 1997, hlm 1

${ }^{2}$ F.A.M Sroink \& J.G Steenbeek, Inleiding in het Staat en Administratief Recht, (Alphen aan de Rijn : Samson HD Tjeenk Willink, 1985), hlm. 26.

${ }^{3}$ Philipus M Hadjon, Hukum Administrasi dan Good Governance, cetakan kedua, (Jakarta : Universitas Trisakti, 2012), hlm. 22.

${ }^{4}$ Philipus M Hadjon, Tentang Wewenang, Op.Cit., hlm 1; Henc van Maarseveen, Bevoegdheid, dimuat dalam P.W.C Akkermans et.al, Algemene Begrippen van Staatsrecht, (Alphen aan de Rijn :Tjeenk Willink, 1985), hlm. 47.

${ }^{5}$ Henc van Maarseveen, Ibid., hlm 49 
harus dapat ditunjuk dasar hukumnya dan komponen konformitas hukum mengandung makna adanya standar wewenang, yaitu standar umum (semua jenis wewenang) dan standar khusus (untuk jenis tertentu).

Ultra vires adalah istilah Latin yang berarti "di luar batas kuasa/wewenang". Istilah ini lazim dipergunakan dalam sistem hukum yang menganut model Anglo Saxon (Inggris), sementara dalam sistem kontinental, khususnya di Prancis dipergunakan istilah excès de pouvoir. Di negara-negara modern, badan administrasi hampir tidak pernah memiliki kekuasaan asli dan tidak terbatas. Apabila tidak menghormati batas-batas wewenang yang telah ditetapkan kepadanya oleh konstitusi atau oleh UU, maka akan dikatakan menurut terminologi Prancis sebagai excès de pouvoir atau menurut terminologi Latin yang dipertahankan oleh model Anglo-Saxon, bahwa dia bertindak ultra vires.

Ketidakwenangan adalah bentuk paling sederhana dari melampaui wewenang/di luar batas wewenang (excès de pouvoir). Hal tersebut mengandaikan bahwa badan administrasi telah mengambil keputusan yang tidak dalam kompetensinya. Secara umum wewenang badan administrasi pertama-tama dibatasi dengan adanya area/domain yang ditentukan baik oleh badan legislator maupun oleh kekuasaan yang membentuk badan administrasi lainnya.

Sering terjadi bahwa badan administrasi merasa tidak mungkin untuk secara mandiri menggunakan semua wewenangnya. Sebagian besar sistem hukum mengakui bahwa mendelegasikan sebagian wewenangnya kepada badan administrasi yang berhirarki lebih rendah diperbolehkan.

Dalam hukum administrasi apabila suatu tindakan atau keputusan dilakukan dengan landasan hukum yang tepat, maka tindakan tersebut merupakan tindakan intra vires (di dalam batas wewenang). Namun, jika tindakan tersebut dilakukan tanpa adanya landasan hukum, maka tindakan itu adalah tindakan ultra vires (di luar batas wewenang). Tindakan intra vires dianggap sah, sementara tindakan ultra vires dinyatakan tidak sah.

Ultra vires dalam hukum administrasi dapat ditinjau baik dalam arti sempit maupun luas. Ultra vires dalam arti sempit berlaku jika badan administrasi tidak memiliki kekuasaan/wewenang substantif untuk membuat keputusan atau dibuat dengan cara cacat prosedural. Ultra vires dalam arti luas berlaku jika ada penggunaan kekuasaan/wewenang yang 
tidak masuk akal atau itikad buruk, kegagalan untuk menjalankan kebijaksanaan administrasi atau penerapan kekuasaan diskresioner secara irasional dan cara yang salah.

Tinjauan yudisial (judicial review) adalah mekanisme terakhir yang digunakan oleh pengadilan untuk dimintakan pertanggungjawaban terhadap badan publik atas tindakan yang dilakukan dan/atau keputusan yang dikeluarkannya. Tujuan tinjauan yudisial adalah untuk memastikan bahwa badan-badan publik telah bertindak sesuai dengan hukum. Merupakan hal yang biasa untuk mendasari dasar judicial review atas konsep substantif dan prosedural dari ultra vires. Yang pertama muncul ketika suatu badan administrasi telah membuat keputusan atau mengambil tindakan yang tidak diizinkan secara hukum, sehingga bertindak di luar kekuasaan/wewenangnya. Selanjutnya yang terakhir muncul ketika suatu badan administrasi telah gagal untuk mengikuti prosedur yang sesuai dalam proses pengambilan keputusannya.

Masalah sentral dalam penggunaan wewenang oleh badan pemerintah adalah legalitas. Ruang lingkup legalitas dari tindak pemerintahan meliputi wewenang, prosedur, dan substansi. Sehubungan dengan hal tersebut, maka permasalahan yang dikemukakan dalam penulisan ini, bagaimana penggunaan wewenang pemerintahan yang termasuk kategori ultra vires (excès de pouvoir) menurut model sistem hukum Anglo Saxon dan sistem hukum Kontinental ?

\section{B. Pembahasan}

Prinsip dari doktrin Ultra vires saat ini yang menjadi perhatian dalam hukum administrasi adalah prinsip substansial yang memiliki kepentingan dan pengaruhnya sendiri dalam skenario hukum, terlepas dari batas-batas yang diberikan oleh hukum. Doktrin ultra vires adalah doktrin dasar dalam hukum administrasi. Doktrin ini mendesripsikan bahwa suatu badan pemerintah hanya dapat menggunakan kekuasaan/wewenangnya dalam batas-batas yang diberikan oleh hukum. Suatu tindakan badan pemerintah bersifat intra vires ketika ia berada dalam batas-batas kekuasaan/wewenang yang diberikan oleh hukum kepadanya, dan sebaliknya tindakan badan pemerintah bersifat ultra vires jika melampaui batas wewenang yang diberikan oleh hukum. Doktrin ultra vires memiliki dua aspek yakni aspek substantif dan aspek prosedural.

\section{Ultra Vires (Excès de Pouvoir) Dalam Sistem Hukum Anglo Saxon.}


Masa pertengahan abad ke-19, doktrin ultra vires menjadi sarana untuk memastikan bahwa badan eksekutif / badan administrasi (terutama badan pemerintah daerah) bertindak berdasar kekuasaan/wewenangnya. Pengadilan memiliki kekuasaan untuk meninjau kembali pelaksanaan kekuasaan/wewenang tersebut guna memastikan bahwa pembuat keputusan belum melampaui batas kekuasaan, atau jika tidak menyalahgunakan kekuasaan/wewenang, dan bertindak ultra vires. ${ }^{6}$ Penggunaan wewenang pemerintahan termasuk ultra vires merupakan tindakan kontroversial untuk pembatalan suatu keputusan administratif berdasarkan pelanggaran terhadap aturan hukum. Hal ini bersifat terbuka dan memiliki efek memastikan, sesuai dengan prinsip-prinsip umum hukum dan penghormatan terhadap asas legalitas.

Salah satu metode klasifikasi untuk membuat doktrin ultra vires sebagai dasar dalam judicial review, apakah telah terjadi pelanggaran aturan keadilan prosedural, kurangnya kekuasaan/wewenang, kekurangan atau melampaui yurisdiksi, ketidakpatuhan dengan persyaratan prosedur hukum, atau nyata-nyata tidak masuk akal. ${ }^{7}$

Prinsip ultra vires didasarkan pada asumsi bahwa judicial review dilegitimasi dengan alasan bahwa pengadilan menerapkan maksud legislatif. Parlemen merasa perlu untuk memberikan kekuasaan kepada menteri, badan administrasi, pemerintah daerah dan sejenisnya. Kekuasaan tersebut akan selalu tunduk pada kondisi tertentu yang terkandung dalam undang-undang. Fungsi pengadilan adalah untuk mengawasi batas-batas yang ditentukan oleh Parlemen.

Prinsip ultra vires digunakan untuk mencapai tujuan ini dalam dua cara terkait. ${ }^{8}$ Dalam pengertian yang sempit, ia menangkap gagasan bahwa lembaga terkait harus memiliki kapasitas hukum untuk bertindak sehubungan dengan topik yang dimaksud (missal lembaga yang diberi kekuasaan/wewenang oleh Parlemen untuk menyelesaikan masalah ketenagakerjaan tidak boleh mengambil yurisdiksi atas masalah non-ketenagakerjaan). Dalam

\footnotetext{
${ }^{6}$ Ian Ellis-Jones, Essential Administrative Law, second edition, (Sydney-London : Cavendish Publishing, 2001), hlm 51

${ }^{7}$ Ian Ellis-Jones, Ibid., hlm 8

${ }^{8}$ Paul Craig, Ultra Vires and the Foundations of Judicial Review, (Maurer School of Law : Indiana University, 1998), hlm 65
} 
arti yang lebih luas, prinsip ultra vires digunakan sebagai sarana untuk memaksakan sejumlah kendala pada cara di mana kekuasaan/wewenang yang diberikan kepada lembaga telah dilaksanakan (dalam hal ini harus mematuhi aturan prosedur yang adil, harus menjalankan kebijakannya sendiri. untuk mencapai tujuan yang tepat dan bukan tidak patut, tidak boleh bertindak secara tidak masuk akal dll).

Dalam model Anglo Saxon, doktrin ultra vires memiliki dua cabang, yaitu ${ }^{9}$ : a) simple (or narrow) ultra vires (ultra vires dalam arti sederhana atau dalam arti sempit); b) extended (or broad) ultra vires (ultra vires dalam arti diperluas atau dalam arti luas). Dalam ultra vires dalam arti sempit, suatu aturan hukum dapat dinyatakan tidak valid jika : 1). bermaksud menangani beberapa masalah di luar ruang lingkup wewenang yang memungkinkan; atau 2). berurusan dengan suatu masalah yang tampaknya berada dalam lingkup wewenang yang memungkinkan, tetapi melebihi batas wewenang yang ditentukan.

Ultra vires dalam arti sempit (narrow ultra vires) juga memiliki dua cabang, yaitu : a) substantive ultra vires - including so called implied ultra vires (ultra vires subtantif - juga disebut ultra vires tersirat); dan b) procedural ultra vires. (ultra vires prosedural).

Selanjutnya ultra vires dalam arti luas (broad ultra vires) juga memiliki dua cabang, yaitu :

a) abuse of power (penyalahgunaan wewenang), yang melingkupi : (1) bad faith (itikad buruk); (2) improper purpose (tujuan yang tidak baik/tidak layak); (3) irrelevant considerations (pertimbangan yang tidak relevan); (4) manifest unreasonableness (nyatanyata tidak masuk akal); (5) lack of proportionality (kurangnya proporsionalitas); (6) uncertainty (ketidakpastian); dan (7) no evidence (tidak ada bukti).

b) failure to exercise power. (kegagalan dalam menjalankan wewenang), yang melingkupi : (1) fettering discretion (mengendalikan kebijaksanaan); (2) acting on a policy (bertindak berdasarkan suatu kebijaksanaan); (3) acting under dictation (bertindak berdasarkan dikte/perintah); (4) sub-delegation (sub-delegasi); dan (5) estoppel.(pengabaian - tidak melaksanakan isi perjanjian karena kurang jelas).

${ }^{9}$ Ian Ellis-Jones, Ibid., hlm. 52 
Apabila dideskripsikan ke dalam suatu ragaan, maka doktrin ultra vires dalam sistem hukum Anglo Saxon sebagai berikut :

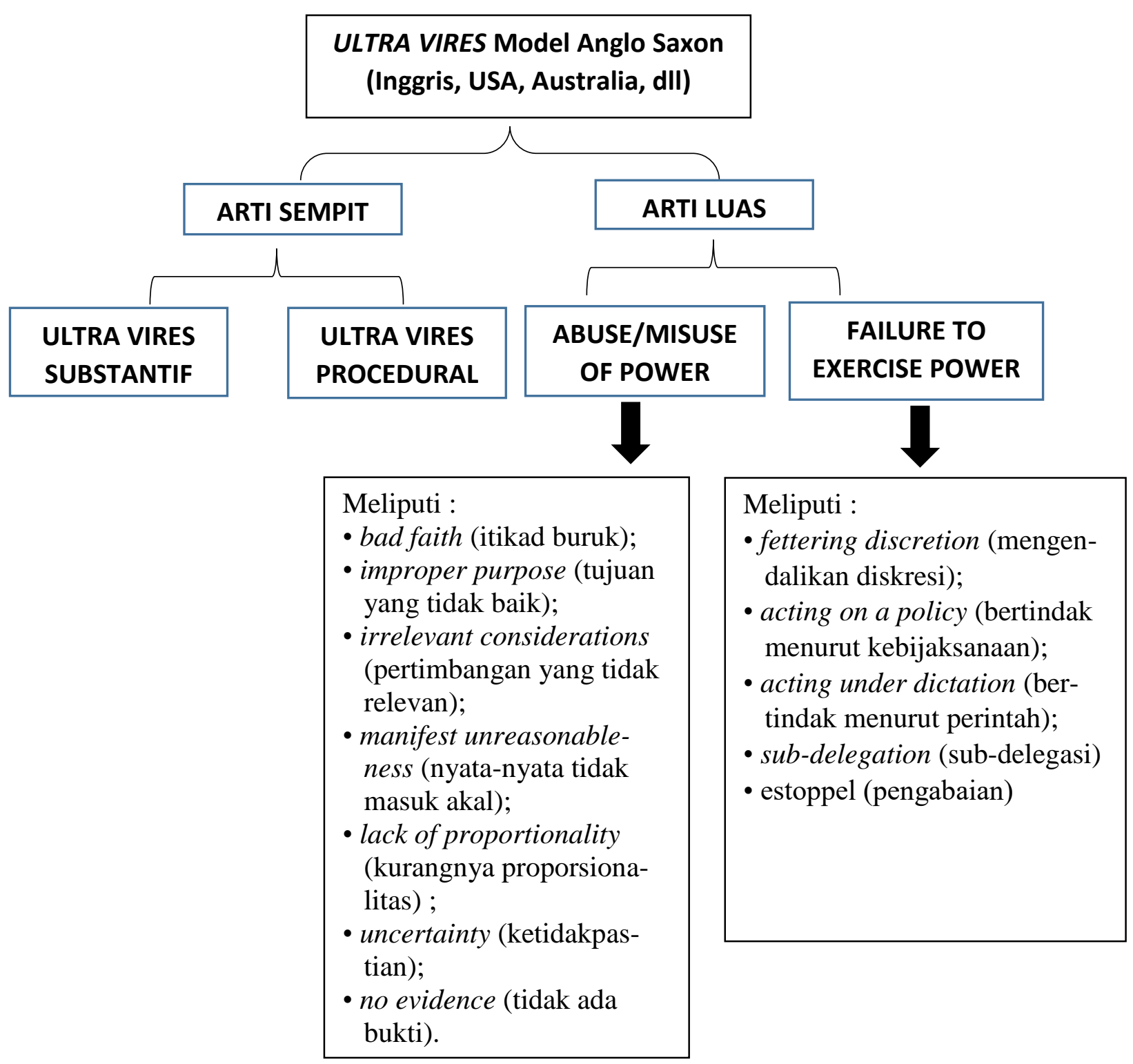

Prinsip ultra vires yang disusun memberikan dasar peradilan untuk intervensi dan juga menetapkan batas-batasnya. Intervensi yudisial semakin dikemukakan pada gagasan bahwa tujuannya adalah untuk memastikan bahwa badan pemerintah tetap berada dalam area yang ditugaskan kepadanya oleh Parlemen. Batas-batas yudisial review juga sangat dipengaruhi oleh prinsip ultra vires. Jika badan pemerintah berada dalam batas wilayah yang ditugaskannya, 
maka itu adalah kontrol pertama yang dilihat (prima facie) dalam melakukan tugas-tugas yang dipercayakan kepadanya oleh legislatif dan karenanya tidak bertentangan dengan kehendak Parlemen. Kontrol atas cara di mana badan pemerintah menggunakan kekuasaannya sendiri, harus dibingkai dalam pikiran badan pemerintah. Pengadilan tidak boleh menggantikan penilaiann badan pemerintah. Kontrol atas cara di mana kekuasaan diskresi dilaksanakan, apalagi dibenarkan dengan mengacu pada maksud legislatif bahwa Parlemen tidak bermaksud badan pemerintah akan membuat keputusan berdasarkan pertimbangan yang tidak relevan atau tujuan yang tidak tepat.

\section{Excès de Pouvoir (Ultra Vires) Dalam Sistem Hukum Kontinental Prancis}

Di Prancis, tindakan excès de pouvoir (melampaui batas wewenang/kekuasaan) adalah tindakan kontroversial untuk pembatalan keputusan administratif berdasarkan pelanggaran terhadap aturan hukum. ${ }^{10}$

Tantangan untuk menyelesaikan excès de pouvoir telah meningkat dalam beberapa dekade terakhir, setidaknya di negara-negara dengan struktur hukum paling kompleks. Peningkatan ini disebabkan oleh beberapa alasan, yaitu : 1). Tindakan badan administrasi telah berkembang pesat : beberapa tugas tradisional, seperti polisi atau pengajaran, menjadi jauh lebih berat; 2). Tugas-tugas baru seperti kesejahteraan atau urbanisme telah muncul; 3). Jaminan yang diberikan kepada warga telah sangat diperkuat; dan 4). Berkat kemajuan pendidikan umum, dan di bawah pengaruh berbagai gerakan protes, warga semakin bertekad untuk mempertahankan hak-hak mereka, jika perlu melalui tindakan hukum.

Kondisi pelaksanaan untuk suatu tindakan badan pemerintah yang melampaui batas kekuasaan/wewenang (excès de pouvoir ) berhubungan dengan : pertama, sifat tindakan yang dipersengketakan dan kedua untuk kepentingan pemohon dalam mengajukan proses. Sarana untuk excès de pouvoir terhadap tindakan pemerintahan hanya terbuka untuk jangka waktu tertentu, setelah itu tidak mungkin untuk mengajukan banding. Tindakan harus

\footnotetext{
${ }^{10}$ Gérard Cornu, Vocabulaire juridique, 7e édition, Presses universitaires de France, Paris, 2005 (ISBN 2130550975), "Recours pour excès de pouvoir", https://fr.wikipedia.org/wiki/Recours_pour_exc\%C3\%A8s_de_pouvoir_en_France
} 
diambil dalam waktu dua bulan setelah publikasi (dalam hal peraturan) atau pemberitahuan (dalam kasus keputusan individu). Namun, ada banyak penyesuaian pada aturan dua bulan, termasuk kemungkinan bagi pengadu/pemohon untuk melakukan banding administratif di hadapan badan yang kompeten dengan memintanya untuk mempertimbangkan kembali keputusannya atau banding secara hierarkis kepada badan yang lebih tinggi dari pelaku tindakan administrasi. Badan pemerintah memiliki dua bulan untuk menanggapi permintaan ini. Dalam hal tanggapan yang tidak menguntungkan atau tidak ada tanggapan dari badan pemerintah, maka periode litigasi (gugatan ke pengadilan) dalam waktu dua bulan dimulai kembali.

Suatu tindakan badan pemerintah untuk dikatakan excès de pouvoir (melampaui batas kekuasaan / wewenang) dapat dilakukan hanya jika tindakan yang dipersengketakan bersifat menentukan, yaitu ia mengubah tatanan hukum. Oleh karena itu tindakan badan pemerintah tersebut harus memiliki ruang lingkup hukum yang memadai, tetapi juga harus mempertimbangkan aspek keputusan dengan tegas, termasuk elemen partikularitas yang mempengaruhi situasi individu tertentu.

Penyelesaian untuk excès de pouvoir sebagian besar terbuka untuk orang-orang yang berperkara, meskipun kualitas warga negara cukup untuk yang melaksanakannya, karena ini bukan "actio popularis". ${ }^{11}$ Agar dapat diterima, itu harus dibenarkan oleh kepentingan yang dapat ditindaklanjuti, yang bagaimanapun sifatnya cukup liberal dan dipahami secara luas sebagai hukum kasus.

Di Prancis, sarana permohonan yang dapat dipergunakan untuk mendukung gugatan terhadap tindakan badan pemerintah yang bersifat excès de pouvoir adalah :

1. Moyens d'illégalité externe (Sarana ilegalitas eksternal), merupakan cara/ sarana yang diambil dari pelaksanaan tindakan, yang meliputi :

a) incompétence de l'auteur de l'acte (ketidakwenangan pelaku tindakan - badan pemerintah) yang bisa bersifat material, teritorial atau temporal;

${ }^{11}$ Action populaire, par laquelle n'importe qui pourrait attaquer n'importe quel acte administratif ou n'importe quelle décision administrative. (Aksi rakyat, di mana siapa pun dapat menentang tindakan administratif atau keputusan administratif apa pun). 
b) vice de forme (dont le défaut de motivation) - cacat bentuk (termasuk kurangnya motivasi);

c) vice de procedure (cacat prosedur);

d) vice dans la composition d'un organisme dont l'avis à recueillir est obligatoire. (cacat dalam komposisi organisasi yang pendapatnya harus/wajib disatukan).

2. Moyens d'illégalité interne (Cara /Sarana ilegalitas internal), merupakan sarana legalitas internal yang diambil berdasar sifat buruk yang terkait dengan konten, hingga substansi tindakan, yang meliputi :

a) violation directe de la règle de droit: (pelanggaran langsung terhadap supremasi hukum);

b) erreur de fait : pour qu'un acte soit légal il faut que les faits sur lesquels il est fondé existent. (kesalahan fakta: untuk suatu tindakan yang legal, fakta-fakta yang mendasari itu harus ada.);

c) erreur sur la qualification juridique des faits (kesalahan pada karakterisasi/ kualifikasi fakta hukum );

d) erreur de droit : substitution des moyens par la decision (kesalahan hukum : penggantian permohonan dengan keputusan);

e) le détournement de pouvoir (penyalahgunaan wewenang), digunakan oleh badan administrasi dalam kekuasaan/wewenang pengambilan keputusan untuk tujuan selain dari yang kekuasaan/wewenangnya diberikan. Ada 3 varian dari détournement de pouvoir, yaitu :

(1) L'administration vise un but complètement étranger à l'intérêt général, comme un but personnel (Badan Administrasi memiliki tujuan/bertujuan untuk mencapai tujuan yang sepenuhnya selain bagi kepentingan umum, dan sebagai tujuan pribadi);

(2) L'administration agit dans un intérêt général mais différent de celui qu'elle est habilitée à poursuivre (Badan Administrasi bertindak untuk kepentingan umum tetapi berbeda dari yang diizinkan untuk dijalankan/ dilaksanakan); 
(3) Détournement de procédure : situation où l'administration met en place une procédure à la place d'une autre non pas en vertu d'une exigence légale mais uniquement dans le but de se procurer un avantage (Penyalahgunaan prosedur: situasi di mana badan administrasi mengimplementasikan prosedur lain, bukan berdasarkan persyaratan hukum tetapi hanya untuk tujuan pengadaan manfaat).

Apabila dideskripsikan ke dalam suatu ragaan, maka doktrin excès de pouvoir (ultra vires) dalam sistem hukum Kontinental khususnya di Prancis sebagai berikut :

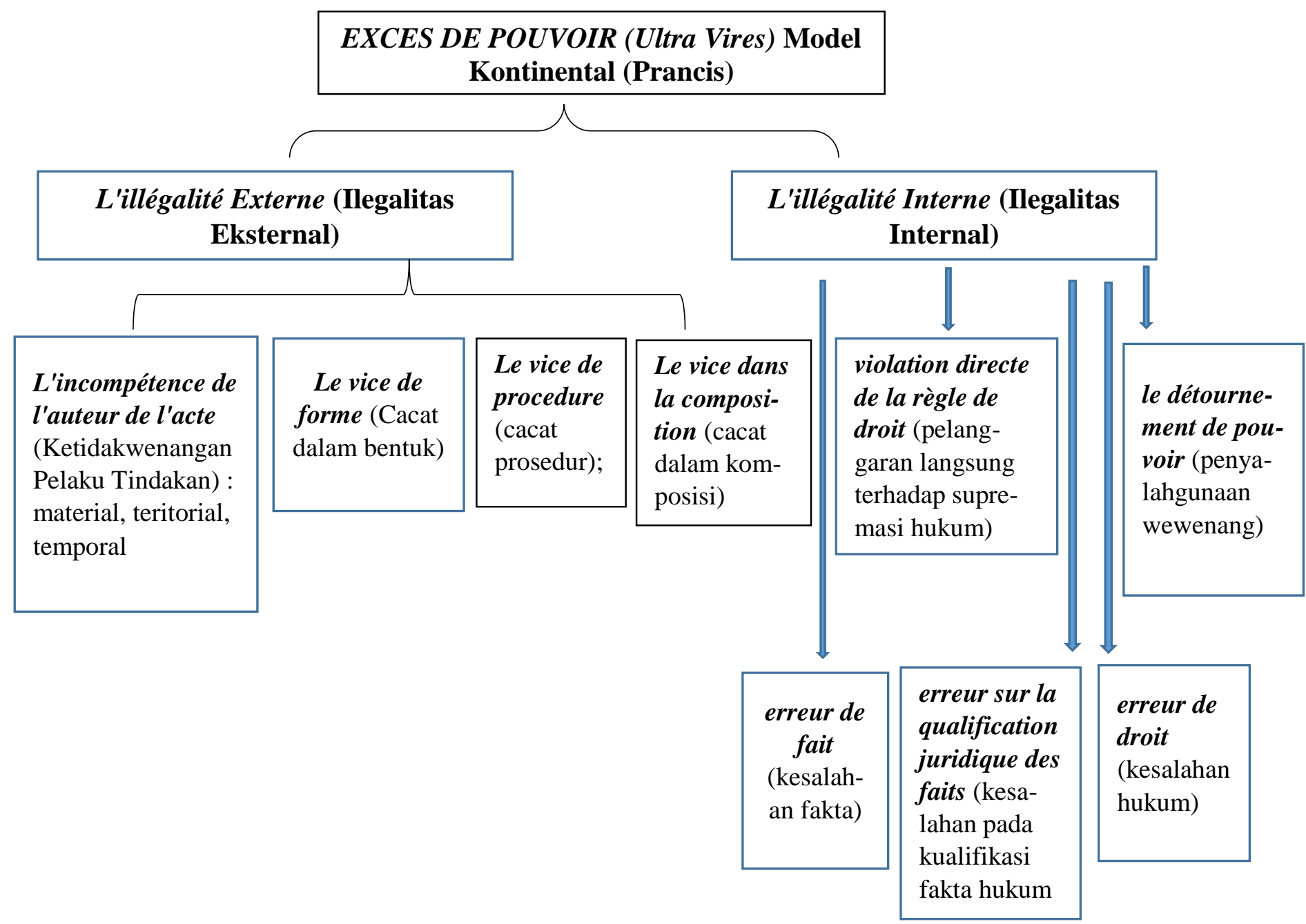




\section{Simpulan}

Sebagai catatan akhir dari penulisan ini, maka dapat diambil pokok-pokok simpulan sebagai berikut : Pertama, Bentuk larangan tindakan badan pemerintah yang berupa excès de pouvoir (ultra vires), baik dalam sistem hukum Anglo Saxon (Inggris, USA, Australia, dll) maupun Kontinental khususnya Prancis meliputi juga larangan penyalahgunaan wewenang (abuse of power, detournement de pouvoir).

Kedua, Larangan penyalahgunaan wewenang (detournement de pouvoir) di Prancis telah dikembangkan ke dalam 3 (tiga) varian, yaitu Badan Administrasi memiliki tujuan/bertujuan untuk mencapai tujuan yang sepenuhnya selain bagi kepentingan umum, dan sebagai tujuan pribadi, Badan Administrasi bertindak untuk kepentingan umum tetapi berbeda dari yang diizinkan untuk dijalankan/dilaksanakan, serta badan administrasi mengimplementasikan prosedur lain, bukan berdasarkan persyaratan hukum tetapi hanya untuk tujuan pengadaan manfaat/penyalahgunaan prosedur).

\section{Daftar Pustaka}

Craig, Paul, 1998, Ultra Vires and the Foundations of Judicial Review, Maurer School of Law : Indiana University, Indiana.

Gérard Cornu, 2005, Vocabulaire juridique, 7e édition, Presses universitaires de France, Paris, (ISBN 2130550975)

Jones, Ian Ellis, 2001, Essential Administrative Law, second edition, Cavendish Publishing, Sydney-London.

Maarseveen, Henc van , 1985, Bevoegdheid, dimuat dalam P.W.C Akkermans et.al,

Algemene Begrippen van Staatsrecht, Tjeenk Willink, Alphen aan de Rijn.

Philipus M Hadjon, 1997, Tentang Wewenang, Jurnal Yuridika, Volume 7 No 5-6, September - Desember

Philipus M Hadjon, 2012, Hukum Administrasi dan Good Governance, cetakan kedua, Penerbit Universitas Trisakti, Jakarta.

Ridwan HR, 2011, Hukum Administrasi Negara, Edisi Revisi, RajaGrafindo Persada, Jakarta.

Sroink, F.A.M \& J.G Steenbeek, 1985, Inleiding in het Staat en Administratief Recht, Samson HD Tjeenk Willink, Alphen aan de Rijn. 